\title{
ASSESSING ECOSYSTEM HEALTH: AN ANALYSIS OF TOURISM RELATED CHANGE AND IMPACT IN KHUMBU VALLEY, NEPAL
}

\author{
G.U. Caravello, A. M. Boselli, P. Bertollo and A. Baroni \\ Dip. di Medicina Ambientale e Sanita' Pubblica \\ Università di Padova - Via L. Loredan \\ 18-35131 Padova, Italy
}

\begin{abstract}
The Khumbu is part of the district of Solukhumbu in Nepal, which includes the most outstanding peak in the world, Mount Everest, and many other peaks greater than $7000 \mathrm{~m}$. A dramatic increase in tourist trekking in the Himalayas has produced positive effects such as an increase in income, but has also resulted in profound social, environmental and cultural modifications including migration, deforestation, biodiversity loss, pollution, and cultural contamination. In order to give a clear view of the environmental conditions in the Khumbu Valley, an evaluation has been made of the socioeconomic, sanitary and water quality conditions using a combination of biophysical parameters, demographic and human considerations. Serious existing problems have been identified. Specifically, superficial waters showed faecal contamination in correspondence with increased anthropogenic pressure. The increasing abandonment of the traditional economy (agroforestry, local trading, etc.) in favour of mass tourism and related commerce has resulted in a profound socio-economic transformation. It has been concluded that more sustainable management of natural resources and more rational tourism planning and development is urgently needed to check further degradation and to meet the growing demands of the local population.
\end{abstract}

Key words: Sagarmatha National Park, Tourism, Water quality, Biotic index, human health.

\section{INTRODUCTION}

The backdrop of this study was the increasing trekking and tourism and the issue of increased tourism-related impacts in Khumbu region. Thus, the primary purpose of our study was to assess and provide a preliminary analysis of the impacts of increased tourism on the valley's ecosystem health, with particular attention to water quality and socioeconomic conditions. A secondary purpose was to suggest ways to mitigate impact and develop tourism that better respects the principles of ecosystem health. A third purpose was to define some essential components of ecosystem health based on the biophysical, socioeconomic and human health elements examined in this study.

Increasingly, ecosystem health is seen as an acceptable and advantageous paradigm with which to monitor and assess the state and condition of ecosystems. It has been asserted that ecosystem health can be defined in an operational manner and assessments of health can, at least in part, be based on objective criteria (Rapport 1998). However, actual health assessments have been mostly restricted to individual health parameters such as ecosystem distress factors and risk factors given that the field is still in its infancy. 


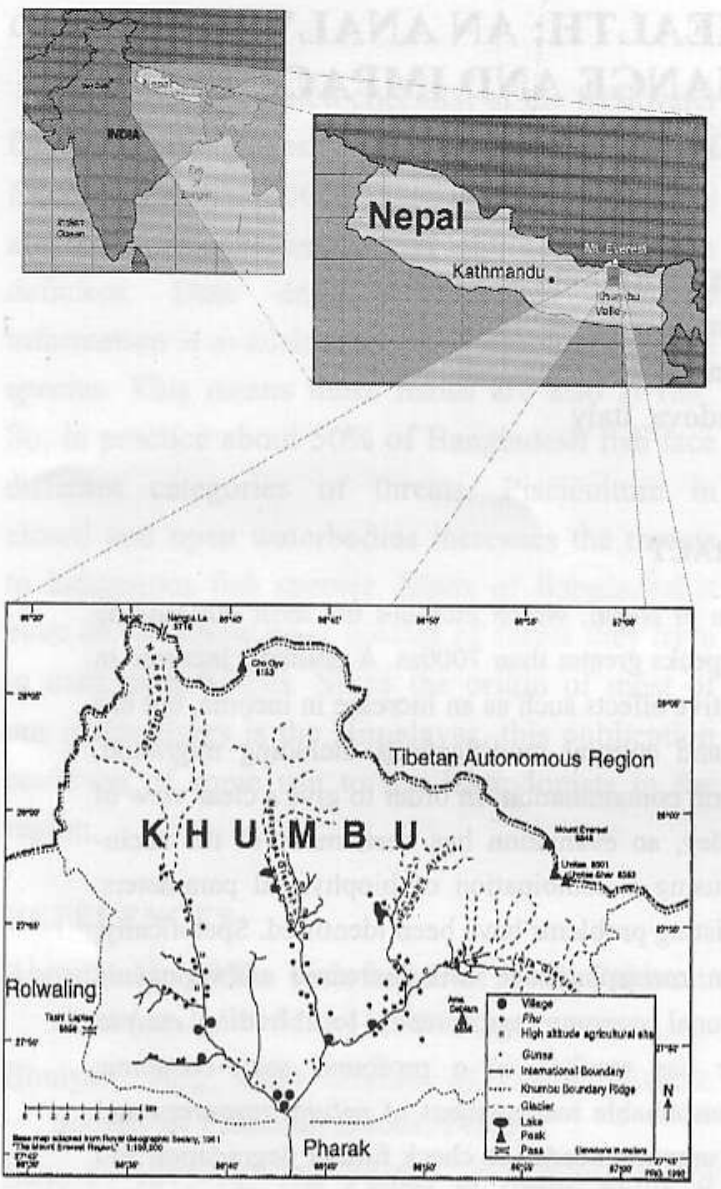

Fig. 1. Nepal and Khumbu Valley settlement patterns (Stevens 1992).

In this case, the paradigm is seen as particularly attractive for two reasons, firstly, the ecosystem under investigation is in large part a modified ecosystem, and secondly, ecosystem health considers humans and human systems as part of the ecosystem, for instance as "cultural landscape" (Farina 2000). It is especially relevant in this case to examine the effects of human-induced environmental change on local human inhabitants, because humans are an integral part of the valley ecosystem.

\section{STUDY AREA}

The Khumbu Valley is a territory along the Nepal and Tibet (China) border (Fig. 1). Lying between the Bhotekoshi and Imja Khola Rivers that flow into the Dudh Kosi which, in turn, flows into the great Sapta Kosi River system, the most widespread in Nepal, and in the sub-Indian continent, second only to the Brahamaputra system (Jha 1992). The hydrographic system of the valley under examination is very often flanked by a network of paths used by the local population for reaching the villages and by the treakkers for reaching the tourist resorts, but above all by those going towards the Base Camp of Mount Everest. Many thousands of people a year take this route, attracted not only by the natural beauty of the area, but also by the competition to conquer the world's highest peak. This massive and aggressive anthropic pressure can be such as to cause serious difficulties to the carrying capacity of the fragile and precious ecosystem. Which is so important as to have been declared a patrimony of humanity by UNESCO (Caspary 1995).

\section{METHODS}

The first consideration of the study was selection of proper indicators and descriptors for a tourism-related ecosystem health assessment. A core set of two classes of integrated environmental indicators was selected based on Bertollo (1998). These two classes consist of socioeconomic conditions and water quality. The integration of these two sets of indicators provides some indication of tourism impact on ecosystem health, comprising both the ecological and human component of the Khumbu Valley System.

In many cases of tourism related development, there is the desire to quantify or assess its "impacts". In purely "environmental" terms, tourism impact is concerned with possible negative effects on biophysical conditions and possible losses of functions beneficial to humans from increased human traffic and use of resources attributable to tourism. 
In this study, the cultural aspect of tourism impact was examined through the investigation of the local socio-economic situation, observation of the demographic profile, population distribution and tourist presence. Data were obtained through consultation of documents from the Central Bureau of Statistics (CBS) and through personal interviews and surveys in many villages of the Valley.

For water quality analysis, various analytical methods were used including site monitoring and laboratory analysis, interviews and personal observations supported by literature. For water quality, both surface and drinking water were analyzed. River water was monitored using sampling stations and potable water using sampling points (source and public taps). Sampling was undertaken during the months of April and May. These two months represent the driest months where water quality pressures are greatest given river flow is at a minimum and the weather is most favorable for tourist trekking. In order to identify the areas where changes in the abiotic and biotic system occur, we located sampling stations along Dudh Kosi, Thame Khola, Bhote Kosi, Imja Khola and Lobuche Khola (Fig. 2).

The analyses were carried out by measuring the physical and physiochemical parameters of temperature $\left({ }^{\circ} \mathrm{C}\right)$, conductivity ( $\left.\mu \mathrm{s}\right)$ dissolved oxygen (mg/l and \%saturation) and hydrogen ion concentration $(\mathrm{pH})$. The possible pollution of water was assayed by two indices: Extended Biotic Index (EBI) and the Microbiological Index (M.I.). The EBI is an organic anthropic freshwater pollution bio-monitoring index based on benthic macroinvertebrate communities inhabiting rivers, streams and creeks (Ghetti 1986). The M.I. is based on enteromicrobial presence (Aerobic count plate, Escherichia coli count plate, Enterobacteriacae count plate and Earst and Mold count plate by $3 \mathrm{M}$ Petrifilm (Siligardi 1986).
In view to evaluating the anthropogenic impact it was decided that a series of interesting indicators, taken from those used for estimation of the quality of superficial waters, could be applied. With this aim in mind biocenotic indicators connected with the community of aquatic macroinvertebrates, long experimented in Europe, in particular in Italy, were chosen. (Ciutti 2000).

To this purpose, one of the research activities carried out by our unit directed its attention to the estimation of the quality of the superficial waters to be found in the area of study. In our case, the aim is to apply a methodology of biocenotic indices, using applications through two protocols of inquiry, I.B.E. (Ghetti 1997) and B.M.W.P. (Alba Tercedor 1996), widely used in Europe also for extreme alpine environments, for monitorig and mapping the territory. These biological mapping of the quality of water was done through the application of biotic indices (I.B.E. and B.M.W.P.) with cartographical method. Both of these indices of quality are based on the study of the benthic macro-invertebrate communities, organisms with dimensions superior to one millimeter who live on the surface of the substrata which form the river bed (epibenthonic) or within the sediments (interstitial). The taxa indicators belong mainly to the fauna group of Insects, Crustacea, Mollusca, Hirudinea, Tricladida and Oligochaeta.

When possible, sampling was undertaken on the diagonal transepts between the two banks, or investigating all of the principal micro-habitats present in the tract under examination along that fraction of the banks of the watercourses. The samples were taken with a handled net with a screw-on collector and a mono-thread nylon net with 21 threads $/ \mathrm{cm}$.

The samples were collected and fixed on the spot in $70^{\circ}$-ethyl alcohol added to glycerin. Then they were transferred to Italy and analyzed with a Zeiss (10-40x) optical stereomicroscope in the laboratories (in our case at the Department of Environmental Medicine and Public Health of the University of Padua.) 


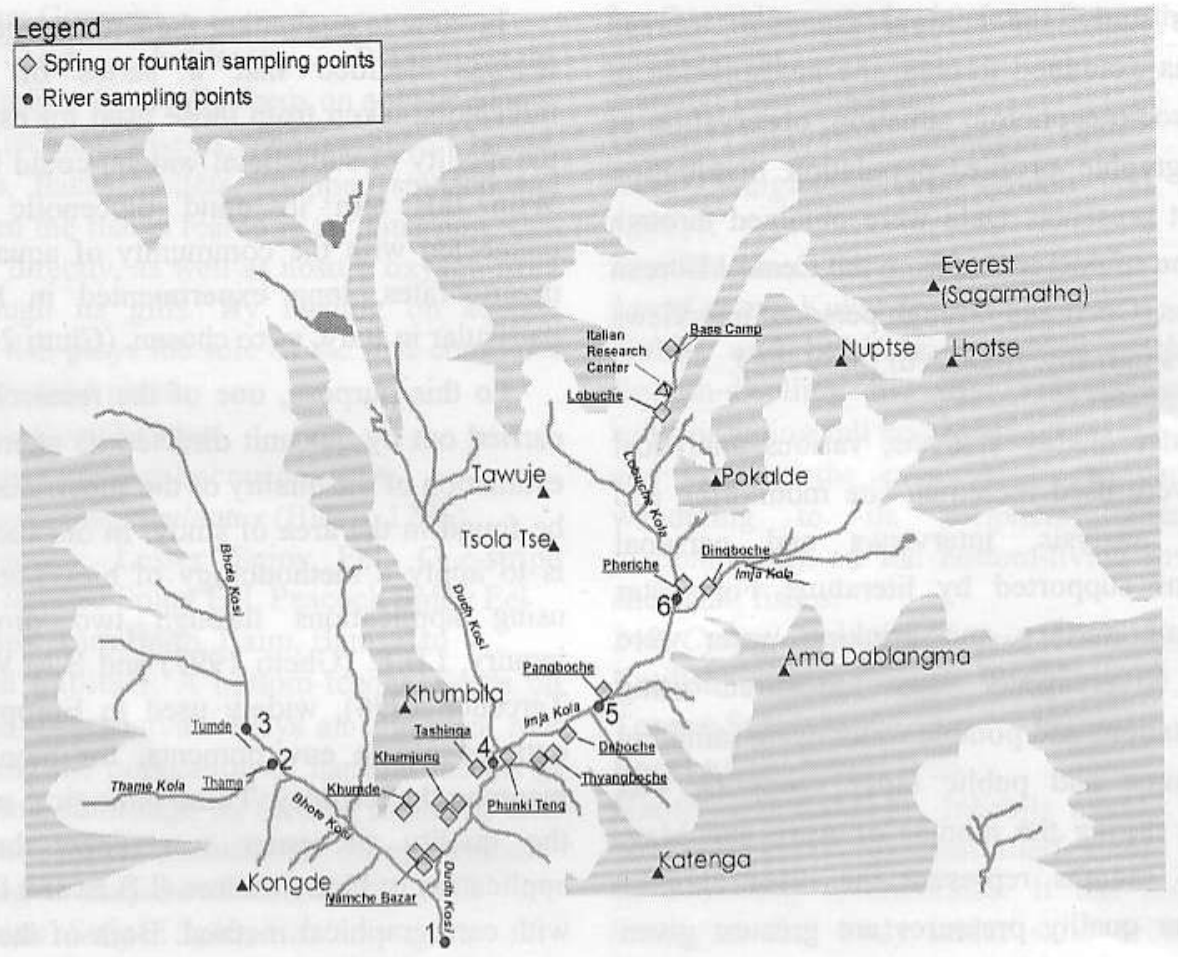

Fig. 2. Sampling points $(1=$ very high, 2 and $3=$ high, 4 and $5=$ medium, $6=$ low $)$.

Table 1. Compulsory taxonomic limits for the definition of Systematic Units in the methods.

\begin{tabular}{|c|c|c|}
\hline \multirow[t]{2}{*}{ Taxon } & \multicolumn{2}{|c|}{$\begin{array}{l}\text { Compulsory taxonomic limits } \\
\text { for the definition of Systematic } \\
\text { Units (SU) in method }\end{array}$} \\
\hline & I.B.E. Index & BMWP' Index \\
\hline PLECOPTERA & Genus & Family \\
\hline TRICHOPTERA & Family & amily \\
\hline EPHEMEROPTERA & Genus & Family \\
\hline COLEOPTERA & Family & Family \\
\hline ODONATA & Genus & Family \\
\hline DIPTERA & Family & Family \\
\hline ETEROPTERA & Family & Family \\
\hline CRUSTACEA & Family & Family \\
\hline MOLLUSCA & Genus & Family \\
\hline TRICLADA & Family & Family \\
\hline HIRUDINEA & Genus & Family \\
\hline OLIGOCHAETA & Family & Class \\
\hline Other taxa & & \\
\hline MEGALOPTERA & Family & Family \\
\hline PLANIPENNA & Family & Family \\
\hline NEMERTINA & Genus & . \\
\hline NEMATOMORPHA & Family & - \\
\hline OSTRACODA & - & Group \\
\hline HYDRACARINA & - & Group \\
\hline
\end{tabular}

The survey proved to be particularly hard both in the field, because of the harsh climatic geomorphologic conditions, as well as the difficult logistic conditions, and in the laboratory, because of the limited specific bibliographic references for the determination of the Himalayan taxa. Therefore, the systematic identification of the collected organisms was carried out by means of European (Campaioli et. al. 1994, Tachet et.al. 1984) and one Asiatic (Dudgeon 1999) dicotomic keys. The classification of the various taxa present in the samples was carried out at the foreseen levels by two methods and in a general line according to family and genera. (Table 1).

Once the structure of the biothonic community had be ascertained these can be useful for both indices, even though the protocols of the values of calculation of the indices are different in the two methods.

ECOPRINT VOL 14, 2007 
A class of biological quality corresponds to each value of the indices, which then is visualized in cartography by means of different colors and the values of reference so as to assign them to their class of quality for the I.B.E.(Ghetti,1997) and B.M.W.P'(Alba Tercedor 1996) indices with their relative, internationally recognized, thematic colors (Table 2). As far as the calculation of the I.B.E. is concerned this was carried out by means of the use of the double entrance table suggested by the method itself (Table 3).

Instead for the B.M.W.P. index the method of calculation was based on the summation of the biotic scores of taxa in the community examined, where each taxa is assigned a variable within the range $1 / 10$. For questions of brevity we refer to the original text for the complete details of the score attributed to each single taxa considered in the protocol.

However, the biologic data is probably affected by a certain peculiarity, due to the particular environmental conditions, altitudes of over $3000 \mathrm{~m}$ asl, which tend towards an under-estimation of the biologic quality of the river ecosystem.

Table 2. Conversible values in Classes of Quality of I.B.E. and B.M.W.P. verdict and color reference.

\begin{tabular}{|c|c|c|c|c|}
\hline $\begin{array}{c}\text { Classes } \\
\text { of } \\
\text { Quality }\end{array}$ & $\begin{array}{c}\text { B.M.W. } \\
\text { P } \\
\text { range }\end{array}$ & $\begin{array}{l}\text { I.B.E. } \\
\text { range }\end{array}$ & Verdict & Colors \\
\hline I -Class & $>101$ & $10-11-12$ & $\begin{array}{l}\text { Not-polluted or } \\
\text { not noticeably } \\
\text { adulterated } \\
\text { environment }\end{array}$ & Blue \\
\hline II Class & $61-10$ & $8-9$ & $\begin{array}{l}\text { Environment } \\
\text { with some } \\
\text { noticable effects } \\
\text { of pollution }\end{array}$ & Green \\
\hline III Class & $36-60$ & $6-7$ & $\begin{array}{l}\text { Polluted } \\
\text { environment }\end{array}$ & Yellow \\
\hline IV Class & $16-35$ & $4-5$ & $\begin{array}{l}\text { Very polluted } \\
\text { environment }\end{array}$ & Orange \\
\hline V Class & $<15$ & $1-2-3$ & $\begin{array}{l}\text { Highly polluted } \\
\text { environment }\end{array}$ & Red \\
\hline
\end{tabular}

Table 3. The Indice Biotico Esteso (I.B.E.) - Extended Biotic Index (Ghetti 1986).

\begin{tabular}{|c|c|c|c|c|c|c|c|c|c|c|}
\hline \multirow{2}{*}{\multicolumn{2}{|c|}{$\begin{array}{l}\text { Key indicator group } \\
\text { (first inside) }\end{array}$}} & \multicolumn{9}{|c|}{$\begin{array}{l}\text { Total number of group (Sistem Unit) present } \\
\text { (second inside) }\end{array}$} \\
\hline & & $0-1$ & $2-5$ & $6-10$ & $11-15$ & $16-20$ & $21-25$ & 26-30 & $31-35$ & $36-\ldots$ \\
\hline Plecoptra present & More than one S.U. & - & - & 8 & 9 & 10 & 11 & 12 & $13^{*}$ & $14^{*}$ \\
\hline (Leuctra*) & One S.U. only & - & - & 7 & 8 & 9 & 10 & 11 & 12 & $13 *$ \\
\hline Efemerotteri presenti & More than one S.U. & - & - & 7 & 8 & 9 & 10 & 11 & 12 & - \\
\hline $\begin{array}{l}\text { (without fam. Baetidae, } \\
\text { Caenidae) }\end{array}$ & One S.U. only. & - & - & 6 & 7 & 8 & 9 & 10 & 11 & - \\
\hline Trichoptera present & More than one S.U. & - & 5 & 6 & 7 & 8 & 9 & 10 & 11 & - \\
\hline $\begin{array}{l}\text { (with fam. Baetidae, } \\
\text { Caenidae) }\end{array}$ & One S.U, only. & - & 4 & 5 & 6 & 7 & 8 & 9 & 10 & - \\
\hline $\begin{array}{l}\text { Gammaridae, Atindinae } \\
\text { and Palemonidae present }\end{array}$ & All above S.U. absent & - & 4 & 5 & 6 & 7 & 8 & 9 & 10 & - \\
\hline Asellidae present & All above S.U. absent & - & 3 & 4 & 5 & 6 & 7 & 8 & 9 & \\
\hline Oligochaeta and & All above S.U. absent & 1 & 2 & 3 & 4 & 5 & - & - & - & - \\
\hline Chironomidae present & & & & & & & & & & \\
\hline All above types absent & $\begin{array}{l}\text { Some organisms not } \\
\text { requiring dissoled } \\
\text { oxygen may be present }\end{array}$ & 0 & 1 & - & - & & - & - & - & \\
\hline
\end{tabular}

* If Leuctra is the only Plecoptra taxon, without contemporaneously Ephemeroptera (except Baetidae and Caenidae), then Leuctra is at Tricoptera level inside. 
These waters, coming from kryal systems, originating in glacial meltwaters, above the tree and vegetation line, should be very oligomineral and oligotrophic. Five stations were set up for drawing groups of samples along the main fluvial axes (Dudh Kosi) and tributaries (Bhote Kosi, Imja Kola and Lobuche Kola) starting at an altitude of $2821 \mathrm{~m}$. up to $4257 \mathrm{~m}$. above sea level (Fig. 2).

\section{RESULTS}

\section{Assessment of Socio-Economic Conditions}

Historians have surmised that the first Sherpa came to the Khumbu five hundred years ago, possibly crossing from Tibet over the pass that heads the Bhote Kosi valley. They brought the language and traditions of their old home to the new. Yak-keeping was part of that transported tradition and is probably the oldest Sherpa occupation. Along with agriculture and trade, animal husbandry enables the Sherpa to live in a forbidding environment of mostly rock and ice. Until 1950, the Khumbu Valley economy was mainly based on agriculture, animal husbandry (yak and its crossbreed), and local trade with the Tingri district in Tibet (cereals exchanged for salt and wool).

The opening of Khumbu to tourism occurred after the first ascent of Everest in 1953. The subsequent construction of bridges, schools, a hospital (Khunde) and airport (Lukla) radically modified the social and economic situation of the population. Today, the Sherpa of Khumbu have added to their traditional occupations those of expedition climber, hotel keeper, tourist guide, government worker, globe trotting trader, and politician. These new jobs reflect the major changes that have come to the area over the last few decades as climbers and other tourists visit Sagarmatha National Park by the thousands (Stevens 1993). By mid 1980s, more than $65 \%$ of the families in Khumbu had direct income from tourism (Sherpa 1987). Sherpas now leave Khumbu for jobs in Kathmandu or schooling in other countries. The once-remote world of Khumbu now becomes predominantly dominated by female and hired labour employed in agriculture, and brought in from south of Khumbu. Thus, the once insulated local population is increasingly involved in the society, economics, and politics of the outside world (Brower 1992), and in the last thirty years the relative isolation of Khumbu has given way with the opening of Nepal's long-closed borders.

\section{Population profile}

According to the Central Bureau of Statistics, there are 830 households for a total population of 3,456 inhabitants in the Khumbu. The gender breakdown is 1,775 males and 1,681 females (CBS 1991). The population is scattered through eight main hamlets included in two village development committees (VDC): Nauje (Namche Bazar), with 1647 inhabitants, and Khumjung with 1809 inhabitants. The population is quite young. The 0 15 age group represent $36.5 \%$ of total population, while those over 55 represent $13.7 \%$ (Fig. 3).

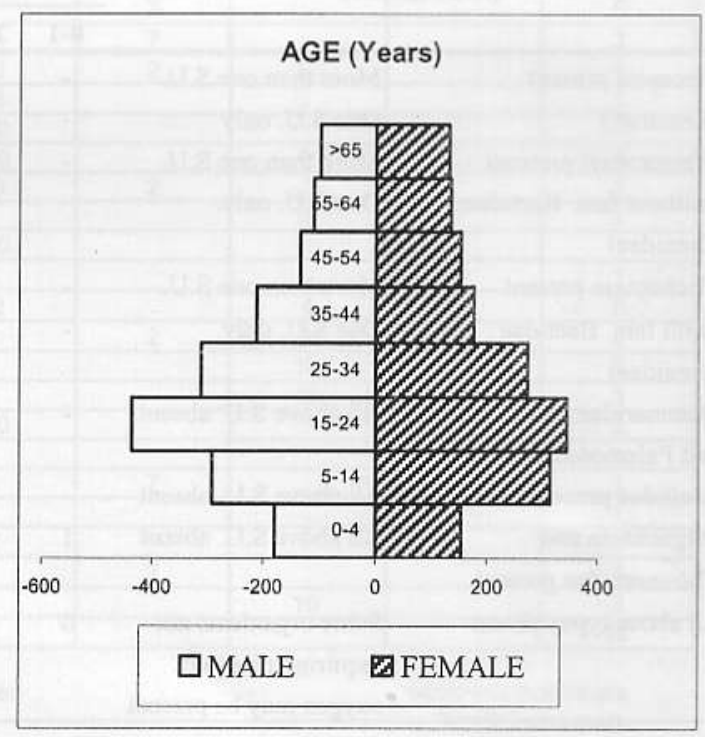

Fig. 3. Population by age and gender

ECOPRINT VOL 14, 2007 
The much reduced $0-4$ age group shows that, in all probability, birth control has been used in the last few years. According to the cultural patterns of courtship and marriage, Khumbu Sherpas today marry relatively late, usually not until after the age of twenty-five. Young men and women are expected to contribute their full labour to the household until the time they marry and leave it (East et al. 1998). The $15-24$ age group shows a migration of young people from the south of Solokhumbu as salaried workers. For room, board, and a monthly pittance, some Khumbu Sherpas have year-round assistants who cut wood, do housework, watch livestock and work fields.

\section{Human settlements}

Sherpa perception, categorization and evaluation of microenvironments greatly influence their selection of group sites and choice of crops and crop varieties. Especially important are the differences that are distinguished between soil types, precipitation patterns, and agricultural growing seasons. More than $97 \%$ of the Khumbu is considered unsuitable for cultivation due to altitude, poor soil conditions, or excessive precipitation. Most of the remaining potentially arable land has never been put into cultivation and remains today in forest, woodland, and grassland. The amount of land that is actually in fields is far less than $1 \%$ of total area of the Khumbu, and moreover, nearly $20 \%$ of this small area is in hay. Level field sites in steep terrain below $4,000 \mathrm{~m}$ are rare and prized, and the eight main villages of the area are close to relatively gentle terrain between 3,400 and $4,000 \mathrm{~m}$.

Half of the total Khumbu population lives in three villages: Nauje $(3,400 \mathrm{~m})$, Khumjung $(3,790 \mathrm{~m})$, and Kunde $(3,820 \mathrm{~m})$ in southern Khumbu (Fig.1). Currently, population distribution is changing, with an increase of buildings for tourists crowded along the main streets of the villages, which have become a continuous line of lodges and markets for trekkers. Village outskirts are largely excluded from this pattern as villagers continue their traditional agropastoral activities. Here, production is only partly dedicated to tourism demands, with these areas becoming partially abandoned during off-season periods of tourist activity.

Another indicator of tourism induced change, and tied to the phenomenon of this flow, is the more frequent transformation of high-altitude herding settlements (phu) and crop areas. These places are also known as "chusa" (livestock place), while herding settlements are sometimes referred to "yersa" (summer place) and "gunsa" (winter place). These installations have been subjected to two distinct fates. One is their transformation into tea houses or lodges with vegetable gardens as they enter the tourism circuit. The other is their diminished use and abandonment as soon as the traditional economy changes into a tourist economy, or when the trekking paths/routes towards Everest change.

\section{Tourist presence and impacts}

The Khumbu Valley is one of the main tourist attractions in Nepal with a dramatic increase in tourist trekking over the last 30 years. In 1964 a total of 20 visitors were recorded in the Khumbu region. In the 1972-1973 autumn-spring tourist season, 3,200 visitors were recorded (Mishra 1973). In the 1977-78 season, an incomplete register showed at least 3,850 trekkers. By 1981, this had jumped to 5,836 . Visitors increased to 9,900 in 1986 and to 11,366 in 1988 - an increase of 37 percent (Fig. 4). A peak of 26,788 followed this in 1999 and 26,683 in 2000. Number of visitors declined thereafter due to political disturbances, and the lowest (13,982 visitors) in the last one decade was recorded in 2002, and then gradually increased to 18,812 visitors in 2003 , and 20,057 visitors in 2004 . 
Along all the main trekking routes, many dwellings have been converted into lodges by simply putting up a sign, and in some cases, a menu. Considering all of Khumbu, the number of hotels and lodges increased from 7 in 1973, to 81 in 1991, with a total of about 20,000 beds. This has produced wealth for Sherpas who own property in villages, or with means to purchase property. Tourism has also been responsible for the opening of many small shops, often in small premises, in front of hotels and lodges, which supply a vast range of goods for tourists. These shops provide an income to other groups besides the Sherpa families of the Khumbu. Especially in the village of Namche, there are a growing number of paid workers coming from the poorest villages of Solu, or other ethnic groups. These include other poor Sherpa families, or the Tamang or Raj people, who have been left out of tourist development. In exchange for board, lodging and a small wage, these workers cut wood, do housework, tend animals, labour in fields, or work as building labourers. Tourism development has also given the local population a chance to invest beyond Khumbu. In addition to owning and managing nearly all the trekking agencies in Kathmandu, other Sherpas invest the profits from tourism in shops or hotels in the capital and other tourism centres. Therefore, Khumbu has become, an island of wealth and the Sherpas represent one of the richest ethnic groups in Nepal (Brower 1991).

However, the increase in tourist traffic has also produced negative effects in both civil society and the natural environment. Economically, one negative impact has arisen from unequal access to the benefits of tourism. Although nearly every family in Khumbu is involved in tourism in some way, for many residents participation is limited to a few weeks per year as porters or farm hands. Moreover, this flux is influencing local customs and provoking social problems in traditional societies. This latter phenomenon is particularly critical given the demographic pyramid at the 1524 and 25-34 age ranges (Fig. 3). Alienated and frustrated young people are often pushed move to the villages or emigrate to larger urban centers in search of greater economic opportunities once the benefits of economic wealth become evident.

Environmentally, forests have been overexploited as a result of tourism-based activities, leading to inevitable environmental degradation (Jeffries 1982). The increase in wealth from tourism is used to construct a myriad of houses and hotels with the consequent increase, especially in the mountain zones, in the use of firewood to cook and heat. The average consumption of firewood in the region of Khumbu has been estimated at $6-7 \mathrm{~kg}$ per tourist per day (Jha 1992). Notwithstanding national park laws which prohibit camping, many groups ignore these laws through the gathering of firewood for cooking and for sale. Deforestation is not the only environmental problem of this area. Overcrowded camping sites and hotels, and incorrect waste disposal also cause environmental degradation. When linked to the careless personal hygiene of both local and tourist populations, poor waste disposal provokes additional health problems.

Recent environmental problems notwithstanding, it should also be noted that environmental change is not something which came to Khumbu only with the arrival of mass tourism. In different forms and degrees of intensity, it has been a corollary of Sherpa settlement and traditional land use for many generations. However, the quality of tourism in the Khumbu valley is calculated as being "hard", or worse than the mixed quality of most Nepalese tourism given the high concentration of tourists in an environmentally sensitive area (Boselli et al. 1998). 


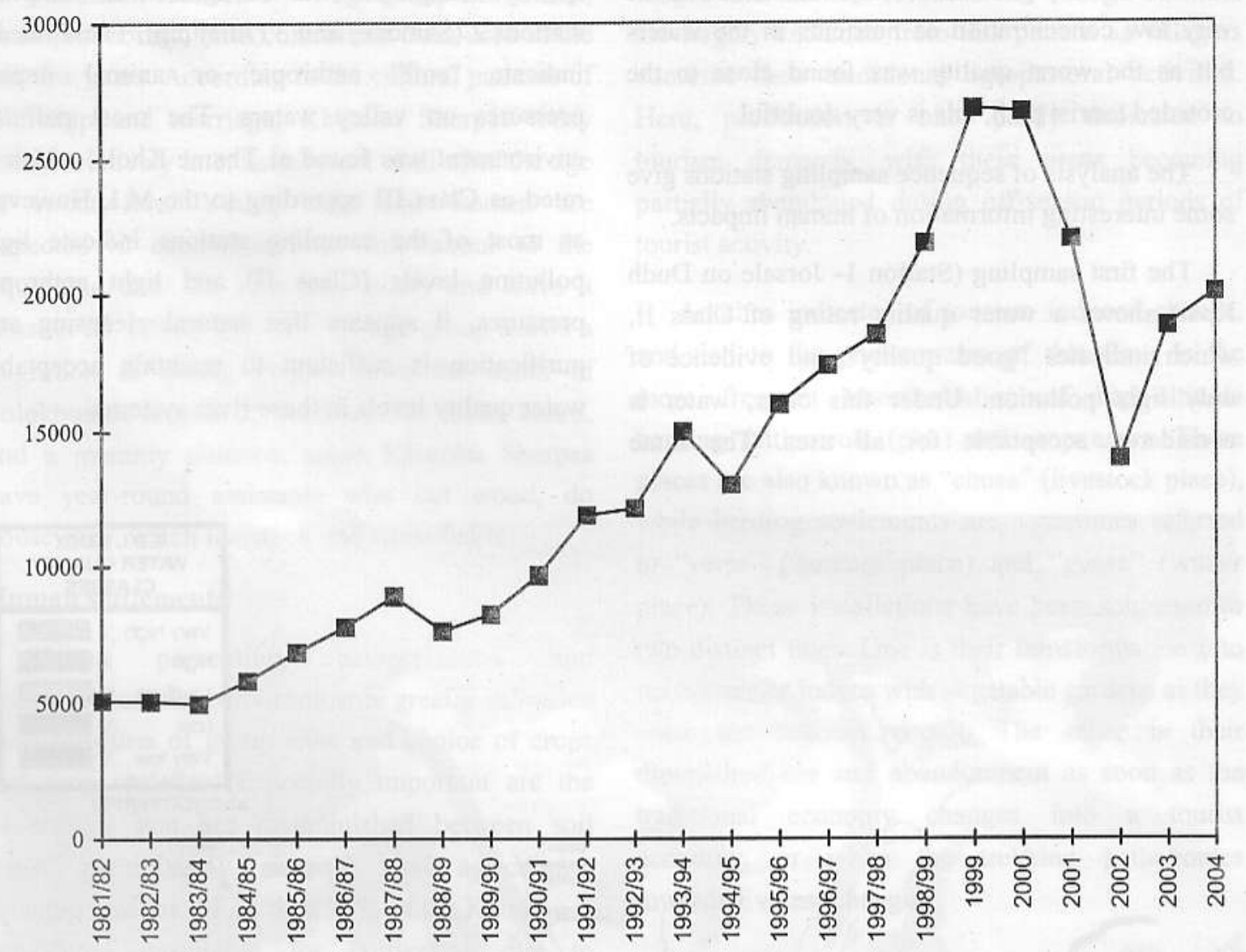

Fig. 4. Tourists in Sagarmatha National Park.

\section{Assessment of Water Quality}

\section{River water quality}

Generally speaking, waters appear to be well buffered, with values between 6 and $8 \mathrm{pH}$, the principal anion is bicarbonate and principle cations are $\mathrm{Ca}$ and $\mathrm{Mg}$. In spite of the complexity of local geology, regional hydrochemistry conforms well to the main lithological variables of the area. As regards trace elements, there appears to be no significant anthropic contamination. Measured concentrations in the Khumbu Valley are generally small, and only uranium is present in high concentrations (20-41 mg/1.) in glacial meltwaters.
Unfurtunately, the same could not be said for the same waters a few years later in 1996 (Caravello et al. 1999) which, when they were monitored even further upstream with another biocenotic index (EBI), proved to be of a very dubious quality with possible signs of organic contamination (Fig. 5). The physical, chemical and biological (micro and macrobiotic) river data collected by water samples (Table 4 ) and by benthic samples give us a problematic situation. The Water Quality Evaluation Maps of the Khumbu Valley by E.B.I. and M.I., have given us some disappointment, because of the relatively low quality of waters, which had previously been 
considered very good. This may be ascribed to the very low concentration of nutrients in the waters but as the worst quality was found close to the crowded tourist path, this is very doubtful.

The analysis of sequence sampling stations give some interesting information of human impacts.

The first sampling (Station 1- Jorsale on Dudh Kosi) shows a water quality rating of Class II, which indicates "good quality" and evidence of only light pollution. Under this class, water is considered acceptable for all uses. The same quality rating/class was recognized in sampling stations 2 (Samdhe) and 3 (Julajung). These results indicate "soft" anthropic or animal impact pressures on valley waters. The most polluted environment was found at Thame Khola, which is rated as Class III according to the M.I. However, as most of the sampling stations indicate light pollution levels (Class II) and light anthropic pressures, it appears that natural cleansing and purification is sufficient to maintain acceptable water quality levels in these river systems.

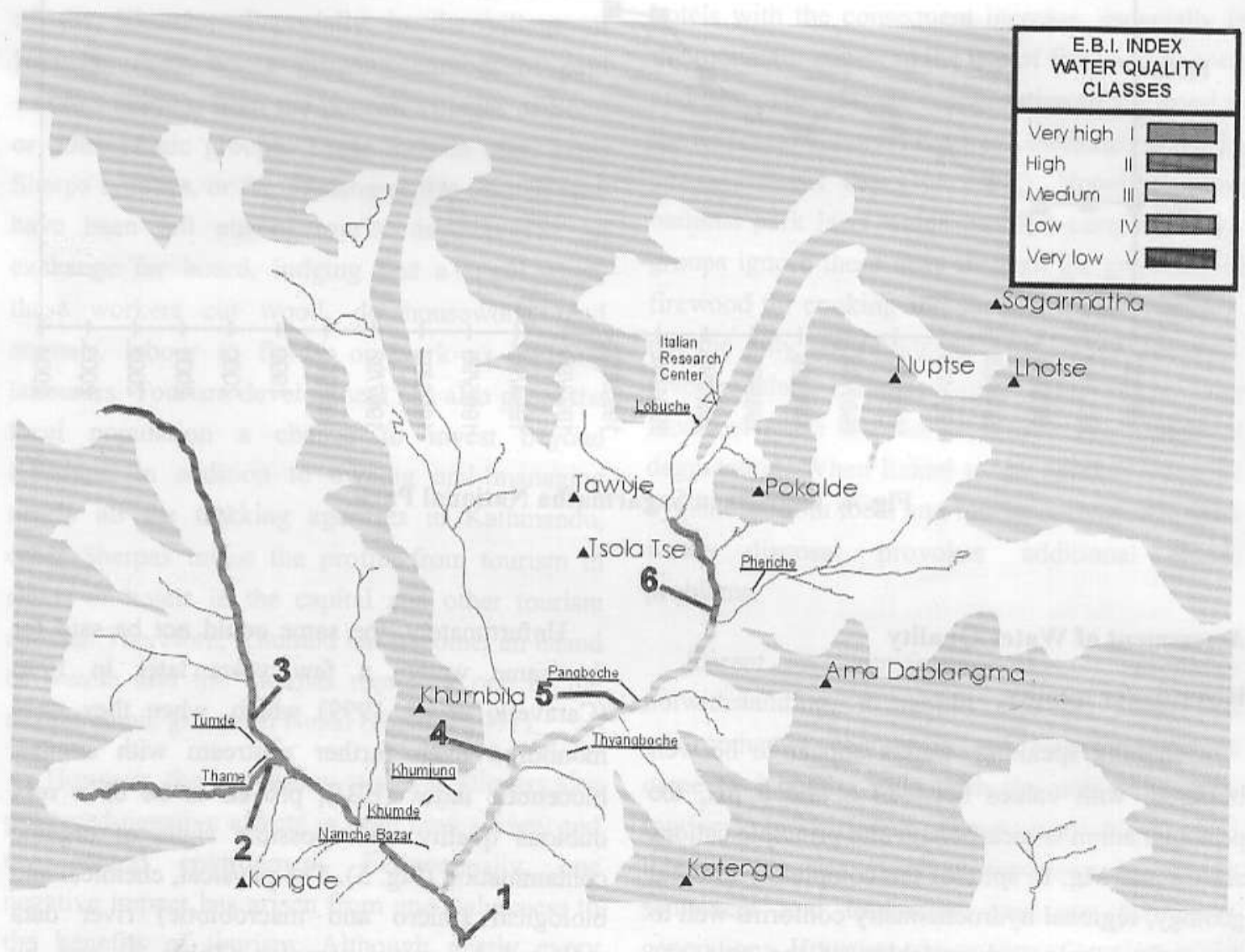

Fig. 5. E.B.I. river water quality (1996) $(1=$ very high, $2=$ high, $3=$ medium, $4=10$ w, 5 and $6=$ very low). 
Table 4. Chemical, physical, bacteriological date and I.B.E. and M.I. class of collected waters samples (1996).

\begin{tabular}{|c|c|c|c|c|c|c|c|c|c|c|c|c|c|c|c|c|c|c|}
\hline Place & Sa & $\begin{array}{l}\text { Aliture } \\
(\mathrm{mi})\end{array}$ & Latilude & Longitude & dale & lime & $\overline{A i n}$ & $\bar{H} \cdot \mathrm{O}$ & UPH & Conduc. & $O_{2}$ & $\mathrm{O}_{2}$ & $\begin{array}{c}\text { CT } \\
\text { UFC1100 } \\
\mathrm{ml}\end{array}$ & \begin{tabular}{|c|}
$E C$ \\
UFC1100 \\
$\mathrm{ml}$
\end{tabular} & $\begin{array}{c}E B \\
\text { UFC100 } \\
m \\
\end{array}$ & $\begin{array}{l}\text { Moulds } \\
\text { and } \\
\text { yeasis }\end{array}$ & & \\
\hline 1 | Jorsale & Duch Kosi & 2.821 & $N 27^{\circ} 46.961^{1}$ & $6^{64} 43.331^{\prime}$ & $27 / 4$ & 12.15 & 1 & $\overline{77,1}$ & 7,51 & 0,030 & 7,87 & 93,2 & 0 & 600 & 300 & 0 & & ||| \\
\hline \begin{tabular}{|l|l|}
2 & Sandhe \\
\end{tabular} & Thame Kola & 3.752 & N227 $49.823^{\circ}$ & $E 80^{\circ} 39.384^{\prime}$ & 2914 & 14,00 & 15,6 & 12,0 & 7,55 & 0,020 & 6,21 & 92,9 & 28000 & 1800 & 900 & 0 & & $=$ \\
\hline \begin{tabular}{|l|l|l|}
3 & Yulaiung \\
\end{tabular} & Bhote Kosí & & & & 3044 & 15.00 & 12,4 & 10,7 & 7,60 & 0,034 & 6,02 & 87,1 & $T$ & $T$ & $T$ & $T$ & $\|$ & \\
\hline 4 Phunki Teng & Dudh Kosi & 3.444 & N27" $49.922^{\circ}$ & $E 80^{\circ} 4.723^{\prime}$ & 4,5 & 10.25 & 13,8 & 11,6 & 6,14 & 0,015 & 3,34 & 52,1 & 2000 & 2800 & 1800 & 100 & ||I & IIII \\
\hline 5 WMilingo & Imga Kosi & 3.830 & N27 $51.001^{\prime}$ & $E 86^{\circ} 49.772$ & 4,5 & 13.45 & 20,5 & 9,7 & 8,00 & 0,043 & 6,46 & 85,2 & 7000 & 5200 & 4000 & 500 & |II & |II \\
\hline \begin{tabular}{|l|l|}
6 & Tsura \\
\end{tabular} & Lobuche Khola & 4.257 & N27.53.288 & $E 80^{\circ} 49.116^{10}$ & $99 / 5$ & 15.15 & 8,5 & 1,8 & 7,39 & 0,040 & 5,91 & 79,5 & 124000 & 2300 & 2500 & 300 & & III \\
\hline
\end{tabular}

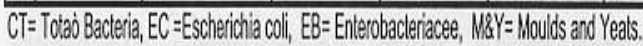

Table 5. Chemical, physical, bacteriological date and I.B.E. and M.I. class of collected waters samples (2000).

\begin{tabular}{|c|c|c|c|c|c|c|c|c|c|c|c|c|c|c|c|c|c|c|}
\hline$n^{n}$ & & $\begin{array}{l}\text { Alitude } \\
(\mathrm{mt})\end{array}$ & Latilude & Alude & dale & iime & Air & ${ }^{\circ} \mathrm{C}$ & UPH & Conduc. & $\mathrm{mgl}$ & $\mathrm{O}_{2}$ & $\begin{array}{c}\text { CT } \\
\text { UFC1100 } \\
\text { ml } \\
\end{array}$ & \begin{tabular}{|c|}
$E C$ \\
UFCH100 \\
$\mathrm{ml}$ \\
\end{tabular} & $\begin{array}{c}E B \\
\text { UFCH100 } \\
\text { ml } \\
\end{array}$ & $\begin{array}{c}\text { Mouds } \\
\text { and } \\
\text { yeasis }\end{array}$ & $|E B| N$ & \\
\hline 1 Jorsale & Duobh Kosi & 2.821 & N27 $46.961^{\circ}$ & $E 80^{\circ} 43.3311^{1}$ & $9 / 5$ & & 22,0 & 10,6 & 6,86 & 0,440 & 6,55 & 83,8 & 370 & 10 & 100 & 72 & 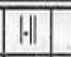 & \\
\hline 2 Thame & Thame Kola & 3.752 & $N 27^{\circ} 49.823^{\prime}$ & $E 80^{3} 39.384^{\prime}$ & $11 / 5$ & 11.50 & 22,0 & 12,5 & 7,44 & 0,330 & 5,15 & 78 & 2000 & 3 & $n c$ & 3300 & $\|$ & \\
\hline 3 Phunki Teng & Dudh Kosi & 3.444 & N227 $49.922^{\prime}$ & $E 80^{\circ} 44.723^{\circ}$ & 1315 & & 19,0 & 10,1 & 6,40 & 0,480 & 4,54 & 60,9 & 1500 & 4 & 200 & 27 & $\|$ & \\
\hline \begin{tabular}{|l|l|}
4 Perche \\
\end{tabular} & Lobuche Khole & 4.257 & $N 27^{\circ} 53.280^{\prime}$ & $E 80^{\circ} 49.110^{\prime \prime}$ & 1956 & & 11,0 & 5,7 & 0,00 & 0,400 & 7,11 & 95 & 150 & 5 & 9 & 250 & $\|$ & \\
\hline 5 Nilingo & Imia Kola & 3.830 & N27' 51.001' & $E 80^{\circ} 49.772$ & 1995 & & 15,0 & 10,9 & 0,00 & 0,350 & 6,45 & 94,5 & 1 & 1 & 1 & 1 & & ||| \\
\hline
\end{tabular}

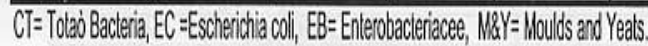

A different situation is apparent in the Dudh Kosi-Imja Khola-Lobuche Khola system. Here there exist the largest villages found along the main route to Everest, and thus a more consistent tourist presence. The water quality of the highest river in the world, the Lobuche Khola, shows light levels of pollution as it is rated as Class II according to the E.B.I. The situation worsens in the Imja Khola river, which is rated as a "polluted environment" (Class III). This is likely attributable to heavy human and domestic animal presence. This dubious situation is reinforced by microbiological ratings of Class III for both indices in sampling Station 4 (Thasingo in Dudh Kosi). The situation improves significantly when the river leaves the Khumbu Valley at the location of sampling Station
1 (Jorsale) (Class II), although waters do not return to a pristine state.

Water quality shows temporal and spatial variation due, directly and indirectly, to anthropic factors, which also have an undesired, if not devastating effects on the aquatic environment. The rivers' water samples of physical, chemical and bacteriological data in our last collection was better than the past (Table 5).

The situation in 2000 , monitored with the IBE Index, shows a biotic structure not so risk (Table 6), however (Fig. 5) the station 1-Jorsle on the Dudh Koshi presents light alterations (Class I-II), while the quality of the waters at station 2-Thame Kola (Class II) are slightly more compromised. 
Unfortunately the situation is more pessimistic for the quality of the waters at the 3-Phunki Teng station on the Dudh Koshi which, clearly showing evidence of pollution (Class III). This also to be found further upstream at the 4-Milingo station on the Imja Kola (Class III), to emerge slightly improved with the waters at the 5 Perice station (Class II), the highest of them all. The situation only changes slightly with the use of the B.M.WW.P' index which, even though it gives better values for the first two stations evaluating them as being cleaner, it totally confirms the pollution class for the more compromised stations.

These results denote an indubitable presence, though not excessive, of pollution connected with the presence of animals and humans pressing on the self-purifying mechanisms of the waters of these valleys. There is lower pressure on the western river system (Thame Khola - Bothe Koshi), where the tourist pressure is lower, or at least only local. While there is more strain on the eastern waters (Dudhi Khosi - Imja Khola -
Lobuche Khola), where there is greater anthropic pressure along the paths and in the infra structure service of trekking towards Mount Everest and nearby destinations that is confermate by heavy value of M. I. in Periche. Proof of this statement comes from the better quality to be found in those parts of the rivers which, because they are deeply embanked in gorges and far from the inhabited areas, are more difficult to be reached by the anthropogenic presence and by their catabolisms.

Besides they are more easily oxygenated and can hence break down the polluting substances more quickly. It is however undeniable, beyond the calculated values of the index, that the clear anthropogenic pressure on these rivers, caused by the increasing massive presence of tourists, create a relatively more heavy impact on these ecosystems, that must be considered as being ecologically very fragile, how show the start of quality lowering in Jorsale water. Then, our results confirm the presence of chemical contamination.

Table 6. Biotic structure and found taxa in Kumbu Valley waters.

\begin{tabular}{|c|c|c|c|c|c|c|c|}
\hline TAXA & $R$ & $\mathrm{~F}$ & $\mathrm{~S}$ & $T$ & $P$ & Other & Ab. \\
\hline Nemoura & 3 & 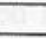 & & 7 & & & 5 \\
\hline Illiesonemoura & 3 & & & 7 & & & 3 \\
\hline Amphinemura & 3 & $\ldots$ & 5 & 2 & - & & 4 \\
\hline Baêtis & 5 & & 5 & & & & 5 \\
\hline \begin{tabular}{|l} 
Rhithrogena \\
\end{tabular} & & & 10 & & & & 4 \\
\hline Iron & & & 10 & 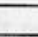 & 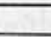 & & 4 \\
\hline LEPIDOSTOMATIDAE & 3 & - & 5 & 2 & & & 1 \\
\hline RHYACOPHILIDAE & & & & & 10 & & 2 \\
\hline ELMIDAE & & 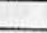 & 10 & & 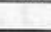 & & 1 \\
\hline SCIRTIDAE & 10 & & & & & & 1 \\
\hline CHIRONOMIDAE & 3 & 1 & 2 & 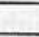 & 4 & & 5 \\
\hline LIMONIIDAE & 3 & - & & 2 & 5 & & 2 \\
\hline EMPIDIDAE & & & & & 10 & & 3 \\
\hline ATHERICIDAE & 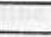 & & & & 10 & & 3 \\
\hline BLEPHARICERIDAE & 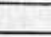 & & 10 & & & & 2 \\
\hline DEUTEROPHLEBIDAE & & & & & & 10 & 1 \\
\hline \begin{tabular}{|l} 
TIPULIDAE \\
\end{tabular} & 3 & & & 7 & & & 1 \\
\hline SIMULIIDAE & & 10 & & 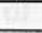 & & & 1 \\
\hline TUBIFICIDAE & 10 & & & & & & 1 \\
\hline OSTRACODA & 8 & & & 2 & & & 1 \\
\hline HYDRACARINA & & & & & 10 & & 2 \\
\hline TOTAL & & & & & & & 52 \\
\hline \multicolumn{6}{|c|}{$\begin{array}{l}R=\text { Gatherer; F= Filter; } S=\text { Scraping; } T=\text { Mincer; } P=\text { Predator; } A=\text { Other. } \\
\text { Abondace in Standard Sample (Moyle) }\end{array}$} & \multicolumn{2}{|c|}{$\begin{aligned} 1=>0 & <=3 \text { individuals } \\
2=>3 & <=10 \text { individuals } \\
>10 & <=20 \text { individuals } \\
\Rightarrow>20 & <=50 \text { individuals } \\
5 & =>50 \text { individuals }\end{aligned}$} \\
\hline
\end{tabular}




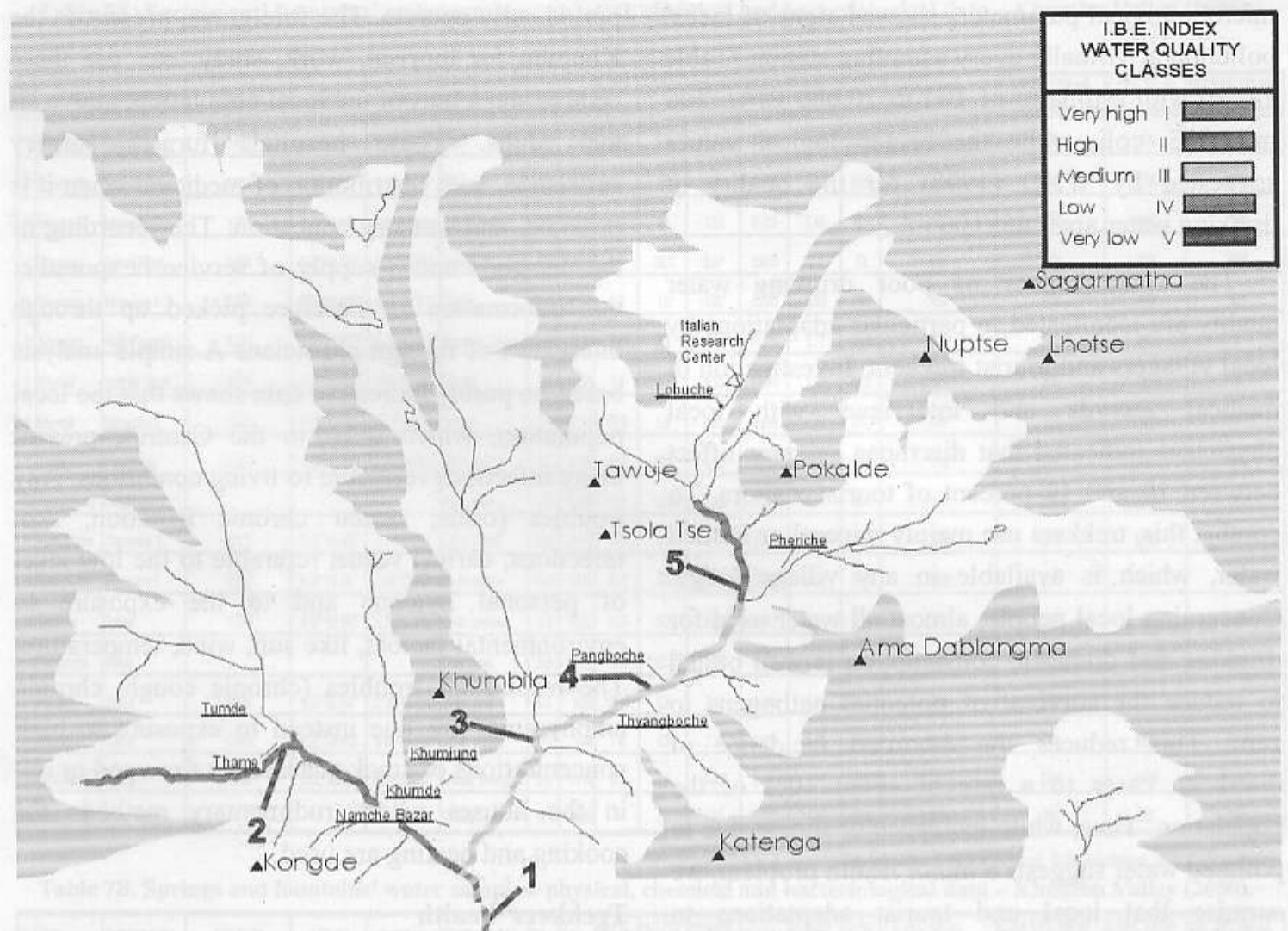

Fig. 6. E.B.I. river water quality (2000) $(1=$ very high, $2=$ high, $3=$ medium, $4=$ low, $5=$ very low $)$.

Another interesting fact, besides the measured qualities, is that it is possible to apply biototic indices also at an altitude of over $4000 \mathrm{~m}$. Indeed, the reported data is also very interesting as a contribution to the discussion about the effective possibilities of using biotic indices in high altitude conditions, which, we feel, to appear both possible and practicable accompanied by the necessary specific calibration of indices protocols

\section{Drinking water quality}

In 1996 and 2000 the drinking waters of 18 fountains and 15 springs have been analyzed in mountain villages along trekking route to Everest Base Camp. The analyses were carried out by measuring of physical and physiochemical parameters as hydrogenion concentration $(\mathrm{ph})$, temperature $\left({ }^{\circ} \mathrm{C}\right)$, dissolved oxygen (OD), $\mathrm{N}^{-\mathrm{NH}_{3}}$,
$\mathrm{N}-\mathrm{NO}_{2}, \quad \mathrm{~N}-\mathrm{NO}_{3}, \quad \mathrm{P}-\mathrm{PO}_{4}$ and microbiological parameters as Enterobacteriacæ, E. coli, Moulds, signs of fecal pollution.

The villages are also totally devoid of any sewage system for the effective disposal of wastewater and human wastes. Human waste disposal depends primarily upon latrines, which are always positioned close to the buildings. While in a convenient location for the disposal of the solid organic waste, they cause raw sewage to seep into the ground thus causing uncontrolled water and ground pollution. Empirical observations were undertaken of domestic water supply sources at Namche, Thame, Khumjung, Khunde, Phunki Teng, Tyanboche, Periche and Lobuche. In 1996 the physical and chemical data confirmed that the drinking water quality is good, instead the 
microbiological parameters showed signs of faecal pollution at virtually every sampling station (Table $7 \mathrm{a}-7 \mathrm{~b})$ with estimates of 100 to $20,000 \mathrm{CFU} / 100$ $\mathrm{ml}$ of $\mathrm{E}$. coli, while the bacteriological values suggested by WHO (1998) for the quality of drinking water are $0 \mathrm{ufc} / 100 \mathrm{ml}$.

The consequences of poor drinking water quality are manifested in particular adaptations by local villagers and tourist trekkers. Investigation of medical records and interviews with local physicians indicated that diarrhoea seizures affect between 10 and 12 percent of tourist visitors. To combat this, trekkers use mainly mineral or bottled water, which is available in any village lodge. Concerning local people, almost all water used for drinking and domestic consumption is well boiled to reduce the survival of potential pathogens to zero. This reduces the recorded incidence of diarrhoea cases to a rate of about $10 \%$ of the population. Thus, while incidence of illness due to polluted water suggests a minor health problem, we surmise that local and tourist adaptations to bacterial pollution minimise the negative consequences of polluted drinking water. In 2000, we observed a best care of fountains in Namche that produced a best protection of the potable waters (Table $7 \mathrm{~b}$ ).

\section{Human Health}

\section{Local population health}

The population of the villages in the Khumbu Valley for the solution of health problems relies above all on traditional popular medicine. We have not observed a real modern presence of sanitary structures in Valley (ambulatory, centres for medications and/or first aid, pharmaceutical services and hospitals). Only partly a definable activity of "Western medicine" was offered in two Centres of the zone in Khunde near the Khumjung $(3,790 \mathrm{~m})$ and in Periche $(4,252 \mathrm{~m})$ where foreign physicians, sent by Volunteer Service Associations and Non Government Organizations (NGOs) periodically operate. The foreigners, present in the Khumbu for tourism, work, study, etc. use these centres and a part of the local population, above all the adults. These hospitals furnish surgery assistance, with distribution of medicine when it is possible, and sanitary education. The recording of the demands and a supply of service is sporadic: our information is therefore picked up through interviews of foreign physicians A simple analysis based on purely indicative data shows that the local population, which turns to the Centres, present many infections referable to living conditions. Any troubles (otitis, ocular chronic irritation, skin infections, caries) seems referable to the low level of personal hygiene and to the exposure to environmental factors, like sun, wind, temperature. The respiratory troubles (chronic cough, chronic emphysema) are due instead to exposure to high concentrations of smoke caused by firewood or oil, in the houses where rudimentary methods for cooking and heating are used.

\section{Trekkers' health}

The foreign travellers and trekkers are affected by pathologies caused by environmental impact, affected by altitude and low temperatures. Trekkers are mainly affected by Acute Mountain Sickness (AMS), commonly called "altitude sickness". For treks bellow an altitude of about $2400 \mathrm{~m}$ AMS is not normally a problem, but it is higher. Many trekkers $(40 \%)$ suffer the classical AMS symptoms like brain aedema, pulmonary aedema and around the $15 \%$ of breathing pathologies. Just around the $10-12 \%$ trekkers suffer short, usually mild, diarrhoea seizures, while all water from taps, streams and rivers in Nepal, even at high altitudes, is contaminated to some degree, in accordance with our data. The takkers in fact use mainly mineral water, available in any village, but food could be dangerous. Lodge hygiene, however, has improved significantly in the last years. 
Table 7A. Springs and fountains' water samples: physical, chemical and bacteriological data - Khumbu Valley (1996).

\begin{tabular}{|c|c|c|c|c|c|c|c|c|c|c|c|c|c|c|c|c|c|}
\hline \begin{tabular}{l|l}
$n^{5}$ & Pase \\
\end{tabular} & Semping point & Altitus: $\mid$ r| & Lalinje & Longinde & Weather rexot & 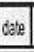 & time & $\mathrm{Br}[\mathrm{Cl}$ & $\mathrm{H}_{\mathrm{O} O \mathrm{PCl}}$ & PATLPसI) & consic. & Q, $[$ myl] & $0, \mid x^{2}$ & TBPJFC100 & $E \operatorname{coli}[\mathrm{UFC} 100 \mathrm{~m}]$ & EDFC 100mi] & DSY PJFC 100 ल] \\
\hline 1 Namche 8. & Cenrad Spring & 3.53 & N22 $48.149^{\prime}$ & E $86^{\circ} 42.654^{\prime \prime}$ & Ceat & 35 & 13655 & 16.9 & 7.7 & 7.21 & 0.045 & 6.47 & 86.3 & 126000 & 800 & 100 & 0 \\
\hline 2 Naanche B. & Chowa Sscring & 3.421 & N22 $48.149^{\prime}$ & E $86^{\circ} 42.554$ & Cear & 3.5 & 1435 & 16.9 & 7.8 & 7.70 & 0.060 & 6.95 & 86.2 & n.a. & 1400 & 1200 & 22100 \\
\hline 3 Kanche B. & Wistiaurn Sx:- & 3.421 & N2278.199' & Es68 $42.654^{\prime \prime}$ & Cera, Gereze & 3.5 & 1500 & 10.9 & 8.5 & 7.53 & 0.918 & 5.49 & 78.1 & 8000 & 1400 & 2000 & 1300 \\
\hline 4 Kuning & School fount & 3.828 & N22 ${ }^{\circ} 49.435^{\prime}$ & E $855^{\circ} 42.300^{\circ}$ & Coudy & 2.5 & $14: 45$ & 9.6 & 10.1 & 6.97 & 0.018 & 6.5 & 93 & 800 & 1500 & 700 & 2500 \\
\hline 5 Kungugn & Menassery F. & 3.828 & N $27^{\prime} 49.435^{\prime}$ & Ess $42.301^{\prime}$ & Cloody & 2.5 & $10: 15$ & 8.9 & 7.6 & 7.02 & 0.020 & 5.55 & 73.6 & 400 & 900 & 700 & 900 \\
\hline 6) Khurizang & Nuijp Fountain & 3.847 & N27 $49435^{\circ}$ & Escos 42.301' & Orecsest, beere & 2.5 & 920 & 9.4 & 8.3 & 669 & 0.020 & 5.77 & 69.8 & 900 & 600 & 500 & 0 \\
\hline 1) Whunde & Hosspial Font. & 3.886 & N22749435' & E $80^{\circ} 42.300^{\prime}$ & Clowsy & 2.5 & 11:10 & 9.4 & 6.7 & 6.93 & 0.015 & 5.16 & 67.5 & 100 & 300 & 0 & 0 \\
\hline 8. Shunded & Mnastey F. & 3.884 & N227 $4943^{\prime}$ & $E B 0^{\circ} 42300^{\prime}$ & Clows: & 2.5 & 12:10 & 13.5 & 5.8 & 661 & 0.016 & 4.77 & 61.3 & 200 & 100 & 100 & 4 \\
\hline 9 Tasinga & Parisping & 3.455 & N22 49.499' & E $86^{\circ} 44,358^{\prime}$ & Clea; breeze & 4.5 & 1130 & 15.9 & 16.9 & 6.92 & 0.017 & 5.43 & 853 & 1800 & 90 & 700 & 500 \\
\hline 10) Fhunis Teng & Loogy Sping & & & & Clear; ind & 4.5 & $14: 00$ & 17.6 & 122 & 7.41 & 0.047 & 6.17 & 86.1 & $n \in$. & 20000 & 160000 & 200 \\
\hline 11 Tyangosthe & Marccethas. & 3875 & N27"50180 & E $80^{\prime \prime} 45.889^{\prime}$ & Clear, breeze & 5.5 & $10: 15$ & 14.6 & 8.5 & 7.11 & 0.017 & 526 & 735 & 1800 & 5200 & 6500 & 0 \\
\hline 12 Tyangobche & Morastey E. & 3846 & N2750.197' & Ess'45:44r' & Clear, breeze & 5.5 & $10: 45$ & 14.6 & 8.5 & 5.55 & 0,050 & 400 & 548 & 1200 & 3500 & 4500 & 1600 \\
\hline 13 Detochie & Ssing & 3753 & N2750,39: & $E 88^{\circ} 46282^{\prime}$ & Clear, breze & 5.5 & 1120 & 14.8 & 53 & 6.39 & 0,012 & 6.4 & 80.7 & 250 & 450 & 0 & 2100 \\
\hline 14 Pangocthe & sising & & & & Clear, wind & s.5 & 14:35 & 166 & 154 & 7.08 & 0.082 & 4.9 & 65.7 & 1900 & 5200 & 7000 & 1500 \\
\hline 15 Pericte & Sxyong & 4285 & N22753.587 & E $666^{\circ} 49250^{\circ}$ & Clear, wind & 6.5 & $9: 30$ & 9.1 & 68 & 7.42 & 0.660 & 4,43 & 392 & 350 & 200 & 0 & 700 \\
\hline 16 Dngobctie & sation & 4,43 & N27'53.543 & E $60^{\circ} 49.7 .76^{\prime}$ & Clear, breezer & 7.5 & 8000 & 7.6 & 8.5 & 7.35 & 0.000 & 6.15 & 89.5 & 45500 & 700 & 850 & 7700 \\
\hline 17 Losuche & Spoing & 4.555 & N27'56.92T & E $866^{\circ} 48.625^{\prime}$ & Cloudy, beeze & 9.5 & $15: 15$ & 8.5 & 18 & 7.39 & 0.040 & 5.91 & 79.5 & 124000 & 2300 & 2550 & 300 \\
\hline 18) & Waler Tank & & & & Coudy & 12.5 & 14000 & . & 7.5 & 5.85 & 0.010 & 4.36 & 60.5 & 400 & 950 & 350 & 300 \\
\hline
\end{tabular}

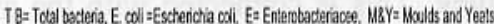

Table 7B. Springs and fountains' water samples: physical, chemical and bacteriological data - Khumbu Valley (2000).

\begin{tabular}{|c|c|c|c|c|c|c|c|c|c|c|c|c|c|c|c|c|c|}
\hline Place & Samplimpodint & Alituste [in] & Lathush & Longiture & Wester repont & sise 5 & $m e$ & $\mathrm{APCC}$ & $\mathrm{H}, \mathrm{OCO}$ & Pसाप्समा & Constic. & $0,[m q)$ & $0_{2}|k|$ & 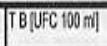 & E. Cor [uFC100 m] & EDFC 100 बin] & 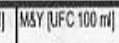 \\
\hline 1 thane & Centra Spring & 3826 & N2r $799.920^{\circ}$ & E\$638.970 & Cloudy & 1115 & 15.45 & 12,0 & 8,4 & 5.5 & 0.24 & 5.28 & 70,3 & 670 & 1 & 145 & 57 \\
\hline 2 Nanche 8. & Centra Spiin & 3.421 & N27 $48.499^{\circ}$ & EE8 42.654 & Sunny & 125 & 1350 & 24,0 & II & 6.60 & 0,40 & 7,30 & 107 & 105 & 12 & 100 & 16 \\
\hline 3 Nanche B. & Vistilisn Spring & 3.421 & N2T'48.149" & 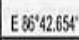 & Sunny & 125 & 1120 & 24,0 & 12,8 & 6.43 & 0,500 & 2.26 & 3,1 & 330 & atsent & 15 & 12 \\
\hline 4 Namche B. & Nistilung Spring & 3.421 & N27'48.494' & 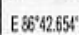 & Sunny & 125 & 114.4 & 240 & 12.2 & 650 & 0.650 & 231 & 33.6 & 1490 & assent & 3 & 28 \\
\hline 5 Kuning & Uonassery Founte & 3.828 & $N 22^{2} 49,425^{\prime}$ & E\%"'42,301 & Oouny & 205 & 15,25 & 18,0 & 10,1 & 1 & 0,200 & 6,43 & 90,4 & 27 & 6 & 18 & 21 \\
\hline 6 Kraming & Najij Founlán & 3.847 & N2r $29.945^{\circ}$ & 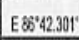 & Qowody & 205 & 15,45 & 18,0 & 8,5 & 1 & 0,090 & 5.56 & 75 & 390 & 3 & 109 & 5 \\
\hline 1 Kundè & Hospia Sping & 3.886 & N27 $79.435^{\circ}$ & E05423.301 & Variable & 215 & 9,35 & 19,0 & 12,4 & 1 & 0,390 & 5.52 & 81 & 40 & absent & 11 & absent \\
\hline 8 Kounda & Wonaster Sxime & 3.854 & N2749.435' & E\$5'423011 & Varable & 215 & 10.05 & 19,0 & 11 & 1 & 0,400 & 5,1 & 75 & $>300$ & 3 & 170 & absent \\
\hline 9 I Tastinga & Spping & 3.455 & N22 $49,455^{\circ}$ & E $85^{\circ} 44,350$ & Coudy & 135 & 1130 & 21,0 & 12 & 7,24 & 0,290 & 5,66 & $\$ 2$ & 476 & 8 & 24 & 12 \\
\hline 10 Tyastoche & Wonaster S Sring & 3.46 & N2750.197" & 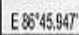 & Surny & $145 \mid$ & 10.15 & 21,0 & 6,4 & 1 & 0,300 & 4,18 & 53,8 & 975 & 7 & 8 & 150 \\
\hline 11 Tyanbocha & Wonastery oentral & 3.875 & N2r ${ }^{\prime} 50.160^{\circ}$ & Ex645.8695 & Sunny & 145 & 9.42 & 21,0 & 8,3 & 1 & 0,210 & 4.92 & 70,1 & 62 & atsent & abseat & 13 \\
\hline 12) Debobche & Spoing & 3.753 & N27'50.092: & 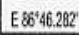 & Sunny & 145 & 1151 & 20,0 & 8,2 & 1 & 0,011 & 4,93 & 65,3 & 28 & atsent & abseat & 70 \\
\hline 13) Prichte & Hispotal swing & 4.255 & N2r'32.587' & ES6 49.250 & Varable & 195 & 110 & 17,0 & 7,3 & 1 & 0,500 & 4,61 & 65 & 215 & atsent & 38 & 50 \\
\hline 14) Ointeches & Soping & 4.343 & N27' $135543^{\prime}$ & Eพ2\%497955 & Couvy windy & 155 & 16.15 & 130 & 11.9 & 1 & 0,280 & 1098 & 172 & 585 & 3 & 290 & 20 \\
\hline 15. Lobuche & Sping & 4.955 & N27's6.927 & E\%648.625 & Coucty & 165 & 1623 & 15.0 & 7 & 1 & 0,790 & 3 & 69,1 & 190 & atsent & absert & 53 \\
\hline
\end{tabular}




\section{DISCUSSION AND CONCLUSION}

In considering the data and subsequent analysis of socioeconomic conditions and water quality, a number of important conclusions have been drawn. Concerning water quality, the observations from this study contradict other studies on anthropogenic contamination (Tartari et al.1991, Reynolds et al.1998), which have reported the surface waters of the Khumbu Valley to be without chemical contamination of human origin. The observations of this study show significant microbiological alteration of water quality. The evidence suggests this is likely caused by organic contamination of faecal origin, and corresponds above all, with greater anthropogenic pressures in the valley in recent years (villages, tourist tracks, lodges etc.). It is notable that qualitative recovery appears to be fairly rapid given the strong and turbulent flow of the waters, which provides rapid oxygenation.

Over the last decade there has also been a profound socioeconomic transformation in the valley. This is connected with the ever-increasing abandonment of the traditional economy to mass tourism and commerce. This has not only modified traditional economic activities, but has also heavily undermined local customs and social organization. Widespread well-being and higher income brought about by recent tourism has pushed aside and subordinated the traditional economy, and driven it into areas not directly touched by tourist paths leading towards Mount Everest. Tourism has also resulted in population displacements as Sherpas from poorer southern areas are attracted to the paid labor related to tourism activities and districts. Tourism has also affected the rural and built landscape, as there has been a marked increase in building without any evident planning criteria.

Thus it is evident that the extremely rapid rise of a significant tourism industry based on trekking has had a significant impact on the valley's ecosystem health. The interconnections described in this study correspond to what can be viewed as a holistic ecosystem health model. This model encompasses three spheres: human inhabitants, socioeconomic activities and the biophysical environment. Under each of these spheres are included human health, biophysical health, and socioeconomic health considerations. The model is depicted in Figure 7 and it is notable that the three elements are interconnected within the entire ecosystem.

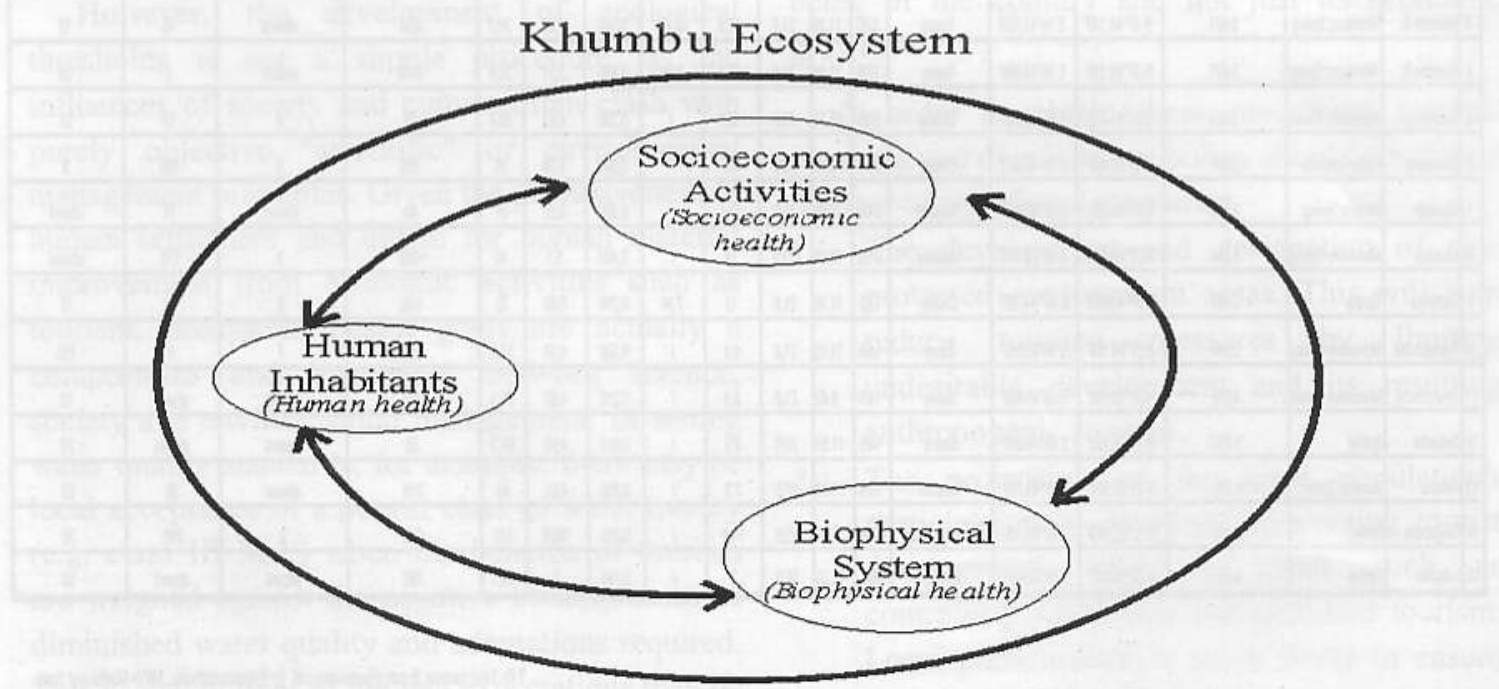

•Fig. 7. Holistic Ecosystem Health Model. 
Table 8. Preliminary Diagnostic Framework for Ecosystem Health in Khumbu Valley.

\begin{tabular}{|c|c|c|c|}
\hline & Issues/Distress Factors & Indicators/Diagnostic Methods & Diagnostic Thresholds/EH Goals \\
\hline $\begin{array}{l}\text { Biophysical } \\
\text { Health }\end{array}$ & 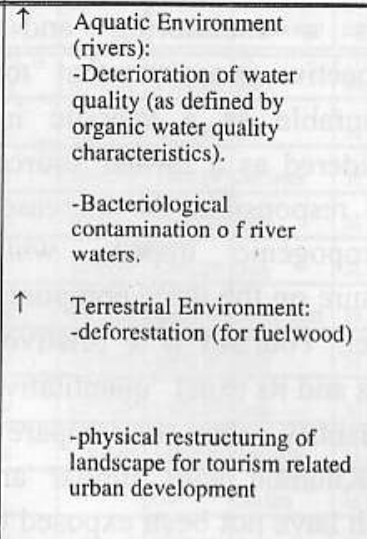 & $\begin{array}{l}\text {-Monitoring of organic } \\
\text { water quality conditions } \\
\text { using appropriate indices } \\
\text { such as EBI. } \\
\text {-Monitoring of } \\
\text { microbiological conditions } \\
\text { using appropriate indices } \\
\text { such as M.I. } \\
\text {-Ground surveying and } \\
\text { remote sensing } \\
\text { reconnaissance. }\end{array}$ & $\begin{array}{l}\text {-Stable or improving organic water } \\
\text { quality conditions - EBI of class II } \\
\text { or less. } \\
\text {-Absence of significant } \\
\text { bacteriological contamination o f } \\
\text { surface waters - M.I. of class II or } \\
\text { less. } \\
\text {-Stable forest biomass quantitics in } \\
\text { protected and vegetated areas. } \\
\text {-Regenerating or increasing forest } \\
\text { biomass in deforested areas. } \\
\text {-Existence of at least rudimentary } \\
\text { community planning. } \\
\text {-Discouragement of de velopment on } \\
\text { steep and unstable slopes }\end{array}$ \\
\hline $\begin{array}{l}\text { Socio-economic } \\
\text { Health }\end{array}$ & $\begin{array}{l}\text { Income and Employment: } \\
\text {-Unequal employment benefits } \\
\text { from tourism growth. } \\
\text {-Unequal income distribution } \\
\text { from tourism growth. } \\
\text { - Population and } \\
\text { Demographics: } \\
\text {-migration of young people from } \\
\text { valley } \\
\text {-increasing tourism presence and } \\
\text { population } \\
\\
\text { Local Culture: } \\
\text { - Loss of local cultural traditions. } \\
\text {-Loss of social cohesion. }\end{array}$ & $\begin{array}{l}\text {-Monitoring of water quality } \\
\text { using quality indices. } \\
\text {-Inventorying and } \\
\text { reconnaissance of forest } \\
\text { resources. } \\
\text {-Proportion of population } \\
\text { served by adequate water } \\
\text { supply infrastructure. } \\
\text {-Proportion of population } \\
\text { served by waste disposal } \\
\text { other than rudimentary } \\
\text { latrines. } \\
\text {-Absence or presence of } \\
\text { rudimentary village } \\
\text { planning. } \\
\text {-Monitoring of employment } \\
\text { activities and employment } \\
\text { levels. } \\
\text {-Monitoring of average and } \\
\text { median incomes. } \\
\text { - } \\
\text { - - Traditional popular } \\
\text { medicine } \\
\text {-Birth, marriage, dea th, } \\
\text { ceremonies. } \\
\text { patterns. } \\
\text {-Monitoring of tourist } \\
\text { presence and population. } \\
\end{array}$ & $\begin{array}{l}\text {-EBI and MI values of II or less. } \\
\text {-Absence of bacterial contamination } \\
\text { of public drinking water supplies. } \\
\text {-Stable or increasing forest areas and } \\
\text { forest biomass. } \\
\text {-Majority or increasing proportion of } \\
\text { local population with access to } \\
\text { unconta minated public water supply. } \\
\text {-Presence of at least rudimentary } \\
\text { village and infrastructure planning. } \\
\\
\text {-Rising employment opportunities in } \\
\text { the valley. } \\
\text {-Rising median incomes in both } \\
\text { traditional and tourism economic } \\
\text { sectors. } \\
\text {-Stable population levels. } \\
\text {-Declining out -migration patterns. } \\
\text {-Sustainable tourism presence } \\
\text { (numbers appropriate to local } \\
\text { infrastructure and resource base). } \\
\text {-Maintenance of local traditions } \\
\text { within constraints of a tourism } \\
\text { economy. } \\
\text { - Maintenance of social stability and } \\
\text { existing positi ve social institutions. }\end{array}$ \\
\hline Human Health & $\begin{array}{ll}\uparrow & \text { Mortality Rates } \\
\uparrow & \text { Life expectancy } \\
& \begin{array}{l}\text { Incidence of illnesses and } \\
\text { disease among resident and }\end{array} \\
& \begin{array}{l}\text { tourist populations } \\
\uparrow \\
\text { Incidence of illness resulting } \\
\text { from bacteriological } \\
\text { contamination of water. }\end{array}\end{array}$ & $\begin{array}{l}\text {-Local hospital and health } \\
\text { records. }\end{array}$ & $\begin{array}{l}\text {-Decreasing infant mortality. } \\
\text {-Increasing life expectancy. } \\
\text { - Decreasing incidence of illness and } \\
\text { disease among local population. } \\
\text {-Reduction or elimination of water } \\
\text { contamination -related illnesses to } \\
\text { minor levels. }\end{array}$ \\
\hline
\end{tabular}


When narrowing the focus to health factors, it is an essential fact that all anthropogenic health factors depend on biophysical health, as the biophysical sphere forms the core of the ecosystem. In the situation described in this study, the new found tourism industry has been embraced for the way it has improved economic conditions (or socioeconomic health) for some components of the local population. This activity, however, has a direct impact on biophysical conditions, as well as influencing other socioeconomic health variables. Changes in biophysical conditions, as a result of socioeconomic changes, result in direct impacts on human health and adaptations given the direct relationship between poor water quality and water borne illnesses.

Depiction of this simple model then leads to the question of what are the essential components of ecosystem health under each sphere if we wanted to assess health, or compile an ecosystem health report card. From this study, a number of issues and health indicator classes have been identified and are listed in Table 8. The table also lists some ecosystem health goals derived from this particular investigation.

However, the development of ecological thresholds is not a simple procedure, as the influences of society and culture often clash with purely objective "scientific" or environmental management principles. Given the pervasiveness of human settlement and desire for human material improvement from economic activities such as tourism, ecosystem health goals are actually a compromise and consensus between science, society and environmental management. In setting water quality standards, for example, there may be local acceptance of a poorer class of water quality (e.g. class III M.I.) when the benefits of tourism are weighed against the negative consequences of diminished water quality and adaptations required. This is also in light of the fact expectations may be low in the short term concerning the installation of proper infrastructure for sewage disposal and drinking water provision.
Finally, some broader conclusions related to tourism have also been drawn from this study. From a monitoring and ecosystem health perspective, it appears that "tourism impact" is not measurable as a specific indicator. It is best considered as a further source of stress as it has been responsible for increased development and anthropogenic impact, which places further pressure on the three components of the ecosystem model. Tourism is a relatively recent source of stress and its exact "quantitative" impact is difficult to quantify unless we compare the overall health of the Khumbu with similar areas in the country which have not been exposed to this type of tourist traffic and development.

Nonetheless, important conclusions and recommendations have been drawn regarding tourism development in the valley. From our evaluations, we have concluded that the challenge Khumbu Valley has to face today is how to promote tourism without compromising the natural, cultural and social environment of the country. That is, to develop tourism that does not damage ecosystems, that promotes the value of "awareness" instead of "consumerism", and that which sustains both the development and well being of the country and not just its economic growth.

In order to obtain these objectives, tourism planning and development policy should consider a number of significant measures:

1. The development and designation of new protected conservation areas. This will help reduce tourism pressures by limiting undesirable development and its resulting anthropogenic stresses.

2. The promotion of the local population's participation in decisions concerning tourist development, and in issues such as controlling admission and qualified tourism. Local participation is more likely to ensure that the benefits of tourism reach a broader constituency. Moreover, the more people benefiting from tourism should provide 
incentives to implement a more sustainable tourism plan.

3. The investigation and implementation of successful tourism development models that have been successfully adapted to local traditions and technologies. These models respect the fact that local populations are more likely to better manage their own natural resources than outsiders as they are most familiar with their surroundings. Also, successful locally adapted economic models will help keep younger generations from migrating and thus help to maintain traditional practices in the long run.

4. Implementation of education and awareness plans for local operators and tourists. These plans should be designed to teach these groups to respect the natural and cultural beauty of Khumbu and the absolute need to protect it. The World Heritage Committee inscribed Sagarmatha National Park on the World Heritage List as an area of exceptional natural beauty and containing spectacular natural phenomena. The Sherpas are also an inseparable part of this landscape as their material and religious culture is closely linked to their natural surroundings.

In conclusion, the Khumbu Valley has great potential for the development of a sustainable model of tourism if it can overcome a limited economic approach based on a lassaiz faire model. While the implementation of sustainable tourism has eluded many regions in both industrialized and developing countries, it is not too late to right the course in this region.

\section{ACKNOWLEDGEMENTS}

We express our sincere thanks to Ev-K2-CNR, Italy for its support to carry out the study. We are also thankful to Nepal Academy of Science and Technology, Sagarmatha National Park, Department of National Parks and Wildlife Conservation, Nepal for their cooperation and making the study visit successful.

\section{REFERENCES}

Banskota, K. and B. Sharma. 1998. Understanding Sustainability in Mountain Tourism: Case Study of Nepal. In: Sustainability in Mountain Tourism: Perspectives for the Himalayan Countries Book Faith India- Studienverlag/ Innsbruck-Vienna. (eds.) East, P., K. Luger, K. Inmann. pp.111-146.

Baroni, A., A.M. Boselli and G.U. Caravello. 1993. Studio della qualità delle risorse idriche nella valle del Khumbu (Nepal). Ambiente Risorse Salute. 14:55-58.

Baroni, A., A.M. Boselli and G.U. Caravello. 1998. Water resources and human health interactions in Nepal and in the Khumbu Valley. In: Top of the World: Mount EverestHimalayan Ecosystem. (eds.) Baudo, R., G. Tartari and M. Munawar M. Bachuis Publisher, Leiden, pp. 235-252.

Baroni, A., A.M. Boselli, C. Bresolin, G.U. Caravello and F. Giacomin. 2000. Tourist impact on environmental and anthropic matrix in the Sagarmatha (Everest) National Park Nepal (Preliminary report). Forum Alpino 2000, 11-15 September Castione della Bresolana, Italy, http://www.mountnet.net/impact.html. Bertollo, P. 1998. Assessing Ecosystem Health in Governed Landscapes A Framework for Developing Core Indicators. Ecosystem Health. 4(1):33-51.

Bertollo, P. 2001. Assessing Landscape Health: A Case Study from Northeastern Italy. Environmental Management. 27(3):349-365

Boselli, A.M., G.U. Caravello, A. Baroni and A. Scipioni. 1998. Nepal: Water, Health, Culture and Environmental Quality Index. In: Research in Human Ecology: An Interdisciplinary Overview. (eds.) Hens L., R.J. Borden, S. Suzuki, G.U. Caravello. VUB PRESS, Bruxells 1998. pp. 217-238.

Brower, B. 1991. Sherpa of Khumbu - People, Livestock and Landscape. Oxford University Press, Oxford. 202 pp.

C.B.S. 1991. Statistical Year Book of Nepal 1991. Central Bureau of Statistics, Kathmandu. 556 pp. 
Camusso, M. and S. Galassi. 1998. Inorganic and organic micropollutants in high altitude and remote areas. In: Top of the World: Mount Everest-Himalayan Ecosystem. (eds.) Baudo, R., G. Tartari and M. Munawar. Bachuis Publisher, Leiden, pp. 143-166.

Caspary, H. 1995. The Cultural Landscape of Sagarmatha National Park in Nepal. In: Cultural Landscape of Universal Value. (eds.) Von Droste B., M. Placheter, M. Rossler, Fisher Verlag Jena/Stuttgart/New York, pp. 154-161.

Ciutti, F. (ed.). 2000. Use of Biotic Indexes to evaluate the quality of freshwater streams: A comparison among four different European methods (IBE, BBI, BMWP', RIUPACS). Biologia Ambientale. 14 (2):37-80.

East, P., K. Luger and K. Inmann. 1998. Himalayan Tourism on Sustainable Trail? An Introduction. In: Sustainability in mountain: Perspectives for The Himalayan Countries. Book Faith India/Delhi and Studienverlag/ Innsbruk- Vienna. (eds.) East, P., K. Luger, K. Inmann. pp. 1-14.

Farina, A. 2000. The Cultural Landscape as Model for the Integration of Ecology and Economics. Bioscience. 50(4):313-320.

Ghetti, P.F. 1986. I macroinvertebrati nell'analisi di qualità deicorsi d'acqua:Indice Biotico EBI, modif. Ghetti Provincia autonoma di Trento (Italy) eds, $104 \mathrm{pp}$.

Goodland, R. 1995. The Concept of Environmental Sustainability. Annual Rewiew of Ecology and Systematics. 26:1-24.

Jefferies, B.E. 1982. Sagarmantha National Park: The impact of tourism in the Himalaya. Ambio. 11: 274-281.

Jha, P.K. 1992. Environment and Man in Nepal. Know Nepal Series no. 5 - Craftsman Press, Bangkok.

Misra, M. 1973. Conservation in Khumbu: The Proposed Mt. Everest National Park. HMG/N.
Rapport, D. 1998. Defining Ecosystem Health. In: Ecosystem Health. (eds.) Rapport D., R. Costanza, P.R. Epstein, C. Gaudet and R. Levins Blackwell Science Ltd. U.K. pp. 372.

Reynolds, B., A. Jenkins, P.J. Chapman and J. Wilkinson. 1998. Stream hydrochemistry of the Khumbu, Annapurna and Langtang regions of Nepal. In: Top of the World: Mount EverestHimalayan Ecosystem. (eds.) Baudo, R., G. Tartari and M. Munawar. Bachuis Publisher, Leiden. pp. 123-142.

Ruggiu, D., R. Bertoni, C. Calleiri, M. Manca and A.M. Nocentini. 1998. Assessment of biota in lakes from the Khumbu Valley, High Himalayas. In: Top of the World: Mount Everest-Himalayan Ecosystem. (eds.) Baudo, R., G. Tartari and M. Munawar. Bachuis Publisher, Leiden. pp. 219-234.

Sharma, S. 1999. Pollution Level of Nepalese Water Resources. In: Nepal-Nature's Paradise. (eds.) Majuparia, T.C. and R. Kumar. Publ. Devi, M, Gwalior (India), Printed Hillside Press Ltd., Kathmandu.

Sherpa, L.N. 1987. Conservation and Management of Biological Resource in Protected Areas whit indigenous people National Park, Nepal. College of Indigenous People. A proposal for forest Research . and Management in Sagarmatha (Mt.Everest) Forest Resourch, University of Washington, Seattle.

Siligardi, M. 1986. Uso di un nomogramma per la costruzione delle Carte Ittiche. Quaderni Ente Tutela Pesca, Udine. 14:163-169.

Stevens, S.F. 1993. Claiming the high ground: Sherpa's, subsistence and environmental change in the highest Himalaya. University of California Press. 537 pp.

Tartari, G., E. Gosso, S. Valsecchi and P. Nino. 1991. Atmospheric deposition and lake chemistry program in the Himalayan region. Documenta, Ist. Ital. Idrobiol. 32:121-126.

W.H.O. 1998. Guidelines for drinking -water quality. Second edition, Vol .2, World Health Organization, Geneva, pp. 973. 